\title{
原著
}

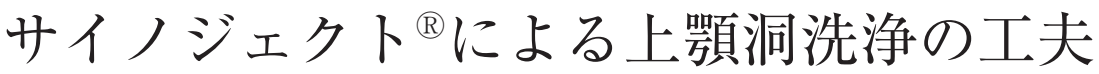

\author{
谷亜希子, 多田靖宏, 小野美穂, \\ 野本 美香, 大森 孝一 \\ 福島県立医科大学医学部耳鼻咽喉科学講座
}

上顎洞穿刺・洗浄法は上顎洞炎に対して古くから行われてきた処置法である。上顎洞炎に対する外科的治療 は, 内視鏡手術の普及により上蕷洞穿刺・洗浄が行われることは少なくなっている。しかし, 入院治療が困難 な場合や，全身的な問題から手術治療が選択できない症例には有効な処置である。われわれはサイノジェクト® を使用することで, 上顎洞洗浄を有効に行うことができた症例を報告する。症例は76歳女性, 左頬部痛を主訴 に受診し, 急性上顎洞穊骨洞炎の診断で入院となった。保存的治療を行うが頬部痛の改善なく, 採血での炎症 反応も増悪傾向にあった。上顎洞洗浄を行う方針とし，下鼻道よりサイノジェクトを用いて穿刺を行った。 膿汁の吸引は確認できたが, 洗浄水の注入は疼痛のため困難であった。そこで 2 本目の穿刺を行い, 2 本目の チューブを介して多量の膿汁, 貯留物を排泄することができた。チューブを留置し 4 日間連日の洗浄を行うこ とで, 所見の改善が認められた。今回用いたサイノジェクトははイプリング式で作動し穿刺針に装着したステ イチューブを留置して膿汁の排泄がなくなるまで手軽に上顎洞内を洗浄することができる。さらに中鼻道の狭 小, 閉塞がある症例でも下鼻道に余裕があれば本症例のように 2 本のチューブを留置し上顎洞内の洗浄や連日 の処置が可能である。

キーワード : 急性上顎洞炎, 上顎洞洗浄, サイノジェクト ${ }^{\circledR}$

\section{Puncture and Irrigation of the Maxillary Sinus Using Sinoject ${ }^{\circledR}$}

\author{
Akiko Tani, Yasuhiro Tada, Miho Ono, Mika Nomoto, Koichi Omori \\ Department of Otolaryngology, Fukushima Medical University
}

Sinus puncture and aspiration are often performed for maxillary sinusitis. We report a 76 -year-old woman complaining of left cheek pain and purulent rhinorrhea, on whom we performed sinus puncture and aspiration using Sinoject ${ }^{\circledR}$. Acute maxillary sinusitis made hospitalization necessary, but chemotherapy did not improve cheek pain and laboratory findings worsened. We therefore performed sinus puncture using Sinoject ${ }^{\circledR}$ via the inferior meatus with an indwelling tube. Pus in the maxillary sinus could not be irrigated because of cheek pain, despite successful aspiration. A second tube via the inferior meatus was indwelled and a large amount of pus was drained. 4 days of maxillary sinus irrigation through a tube led to improvement. The need for sinus puncture and aspiration has decreased, because of advancements in endoscopic sinus surgery, however, a procedure for sinus puncture in patients who cannot be hospitalized for surgery is needed. The Sinoject ${ }^{\circledR}$ is a spring-activated instrument specifically for sinus puncture. It is used to insert a tube into the maxillary sinus. When narrowing or obstruction of the middle meatus prevents irrigation of the maxillary sinus, the placement of 2 tubes through the inferior meatus is useful.

Key words : acute sinusitis, sinus puncture and aspiration, Sinoject ${ }^{\circledR}$ 


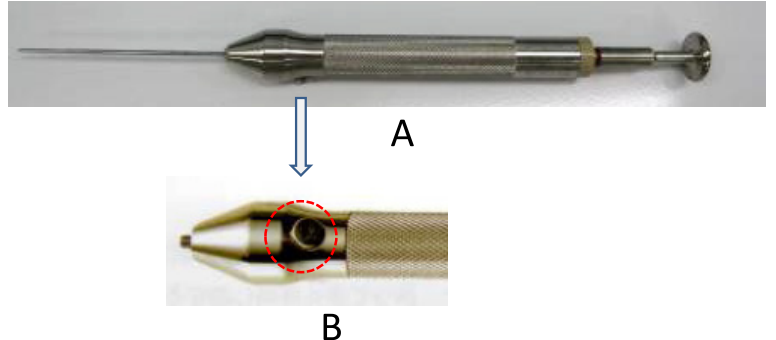

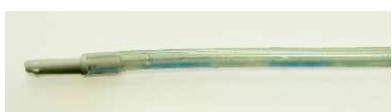

C

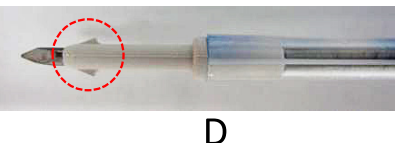

図1 サイノジェクト®A：サイノジェクト®本体。B：拡 大図。ボタン（丸印）を押すことで穿刺針が $10 \mathrm{~mm}$ 前 方に移動する。C：ステイチューブ。上額洞内に留置 するためのチューブ。D：ステイチューブを穿刺針に セットし上靧洞穿刺を行う。突起 (丸印) があるため 上顎洞内に留置が可能である。

\section{はじめに}

上顎洞穿刺・洗浄法は上顎洞炎に対して古くから行わ れてきた処置法である。抗菌薬や内視鏡手術の発展によ り，急性上顎洞炎に対する上顎洞穿刺を行う頻度は減少 している。今回, サイノジェクト（図1）を用いた上 顎洞穿刺・洗浄を行い急性上顎洞炎の治療を有効に行う ことができた症例を報告する。

症例呈示 : 76歳女性

主訴 : 左煩部痛

既往：慢性関節リウマチ，糖尿病，気管支拡張症の診 断で近医内科通院している。アムロジピン, グリメピリ ド, ラロキシフェン, ランソプラゾール, メトトレキサー ト, ジクロフェナク, ポリカルボフィル, アンブロキソー ル，サラゾスルファピリジンを内服中である。

現病歴：感冒症状後より膿性喀痰が 3 週間持続してい た。2 日前より左煩部痛を主訴に当院救急外来を受診し 急性左上顎洞穊骨洞炎の診断となった。煩部の腫脹は認 めなかったが疼痛が強く，頻回の通院処置が困難である ことから入院管理とした。

入院時所見：体温36.7度。基礎疾患のため歩行は困難 であった。顔面の腫脹はなかった。鼻内は左中鼻道から の膿汁排泄を認めたが，鼻中隔彎曲のため十分な中鼻道 処置が困難であった（図 2 ）。外来診察後に右手の震え， しびれ，意識レべルの低下を認め脳梗塞が疑われたが， 神経内科診察にて心因性反応と判断された。

採血所見：WBC $6900 / \mu \mathrm{l}, \mathrm{Hb} 12.4 \mathrm{~g} / \mathrm{dl}, \mathrm{Plt} 195 \times 10^{3} / \mu \mathrm{l}$, CRP $3.60 \mathrm{mg} / \mathrm{dl}$, HbAlc $8.1 \%$

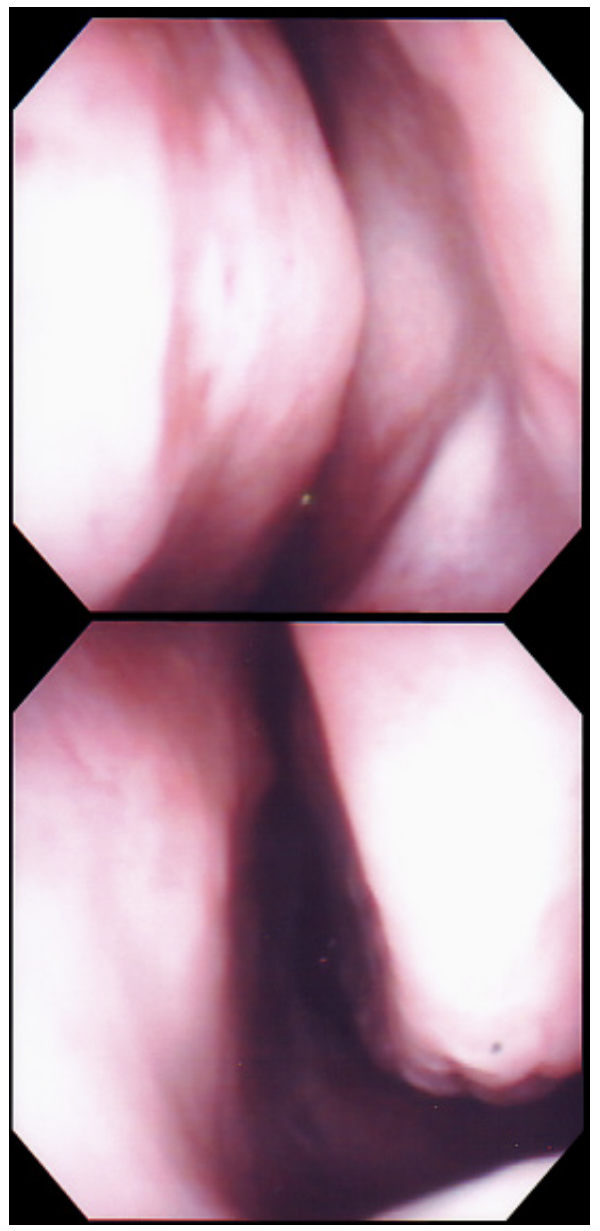

図2 入院時鼻内所見。上段 : 左鼻哚上方。鼻中隔が張り出 し中鼻甲介，中鼻道は十分に観察できない。下段：左 鼻腔下方。前鼻からの観察では膿汁は明らかでない。

CT所見（図 3)：右鼻副鼻胿には炎症所見を認めな かった。鼻中隔は緩やかに左に彎曲していた。左中鼻道 は狭小して扔り左上顎洞および前部篩骨蜂巣は軟部陰影 で充満していたが，左上顎洞内部に石灰化病変や骨破壊 像は認めなかった。皮下組織の腫脹は認めなかった。

入院後経過：臨床所見，検查所見上り左急性上顎洞節 骨洞炎と判断した。CTRX $2 \mathrm{~g} /$ 日の静脈投与, 中鼻道開大 処置，CMXネブライザーが施行されたが疼痛の改善は 得られなかった。入院 3 日後の採血ではCRP $6.19 \mathrm{mg} / \mathrm{dl}$ と炎症反応が増悪傾向にあり入院 4 日目より抗菌薬を $\mathrm{PAPM} / \mathrm{BP} 1 \mathrm{~g} /$ 日に変更した。外科的治療も検討された が鼻内視鏡下手術は本人の心身状態より困難と判断し た。操作が短時間で，上顎洞内貯留液の排膿，洗浄が有 効にできる方法としてサイノジェクトをを用いた上顎洞 穿刺を選択した。

入院 4 日後, 中鼻道, 下鼻道に表面麻酔を行ったうえ で左下鼻道経由で左上顎洞穿刺を行った。上顎洞内に久 


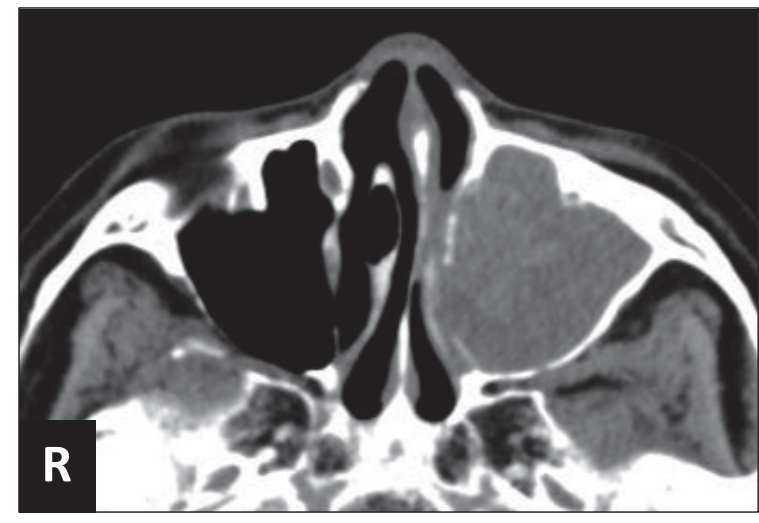

A

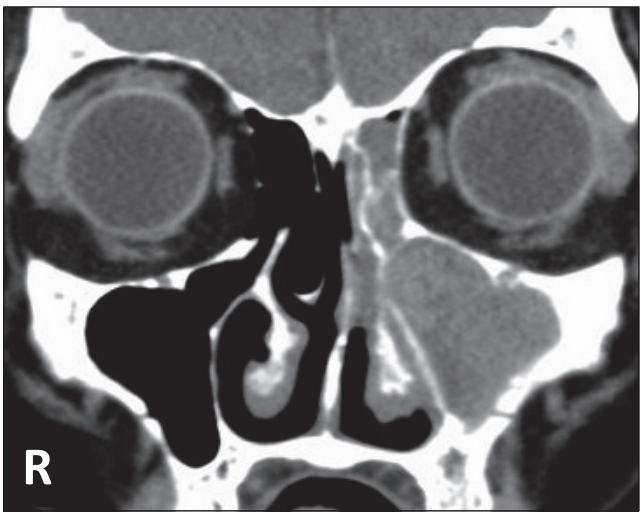

B

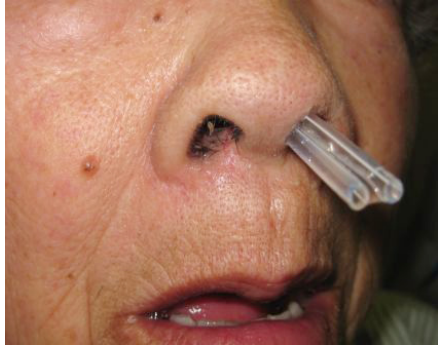

A

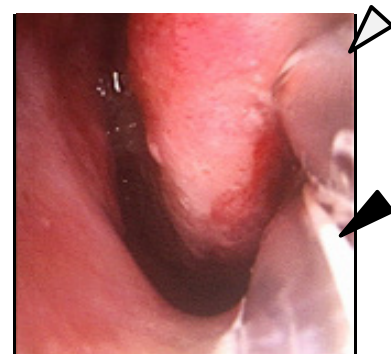

B

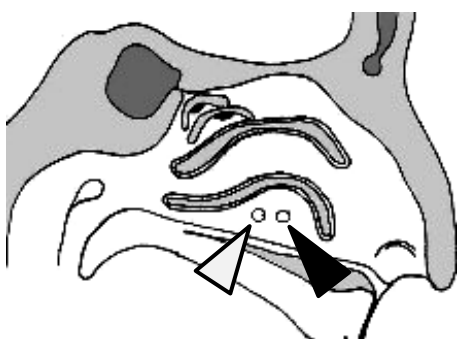

C

図4 サイノジェクト ${ }^{\circledR}$ 抻入後チューブ留置。A：外観。B：内視鏡所見。下鼻道に 2 本（白矢頭, 黒矢頭）のステイチューブが 留置されている。C : 穿刺部シェーマ。2 か所（白矢頭, 黒矢頭）に穿刺し, チューブの留置を行った。

テイチューブを留置し，引き続き上顎洞洗浄を行う目的 で生理食塩水を注入すると左眼, 煩部の痛みを訴えた。 中鼻道の狭小があり十分な排泄路が確保できていないこ とが原因と考え, 下鼻道後方に排泄路のためのステイ チューブを留置することとした。下鼻道に 2 本のチュー ブを留置すると (図 4 ), 痛みなく洗浄を行うことができ, 多量の膿汁排泄を確認できた。

翌日より㚘部の痛みは著明に改善し，ステイチューブ より計 4 日間の洗浄を行った。上顎洞への抗菌薬注入は 行わなかった。

入院後 7 日目のCT画像では上顎洞内の貯留液が減少 し (図 5 ), 採血検查でCRP $1.71 \mathrm{mg} / \mathrm{dl}$ と明らかな改善 を認めたためチューブを 2 本とも抜去し，入院後 15 日で 退院した。上顎洞内の培養結果はPseudomonas. aerginosaであった。

\section{考察}

1）上顎洞穿刺・洗浄について

上顎洞穿刺・洗浄は古くから副鼻腔炎に対する治療と して行われている手技である。急性鼻副鼻腔炎の14日以 内の症例では症状改善に有用であり，抗菌薬投与で改善 の認められない場合や高度病変で疼痛など自覚症状の強 い場合には適応とされる ${ }^{1)}$ 。施行頻度は薬物の発達や内 視鏡手術の普及により減少しているものの，外来診療を 行ううえで必要な手技である。上顎洞穿刺には下鼻道経 由, 中鼻道経由, 犬歯窩経由の 3 通りがあるが2), 急性 炎症に対する上顎洞穿刺では下鼻道経由の報告が多い。 上顎洞探膿針にはSchmidt式が用いられることが多く, 下鼻道より上顎洞内に穿刺し, 膿汁の確認, 採取, 抗菌 薬の投与，洗浄が可能である。本症例は鼻中隔彎曲症が あり，中鼻道の狭小も認めるため，本来であれば鼻中隔 矯正術や上顎洞根本術を行うことで速やかに炎症の改善 


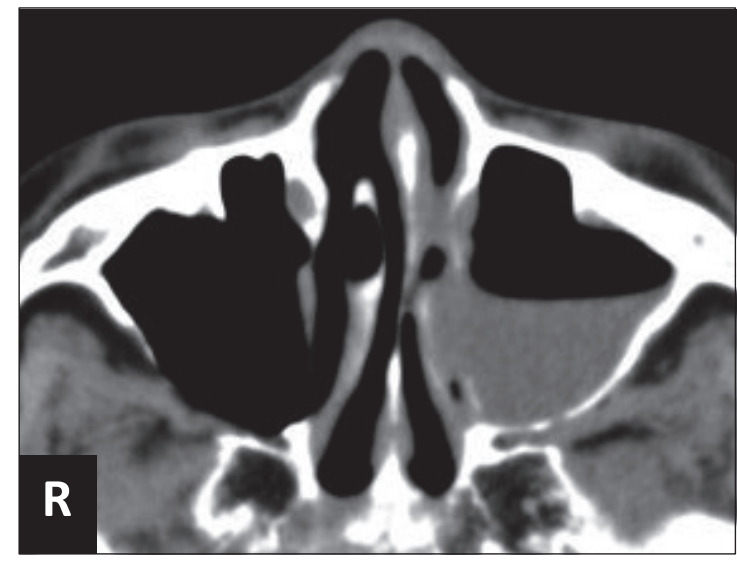

A

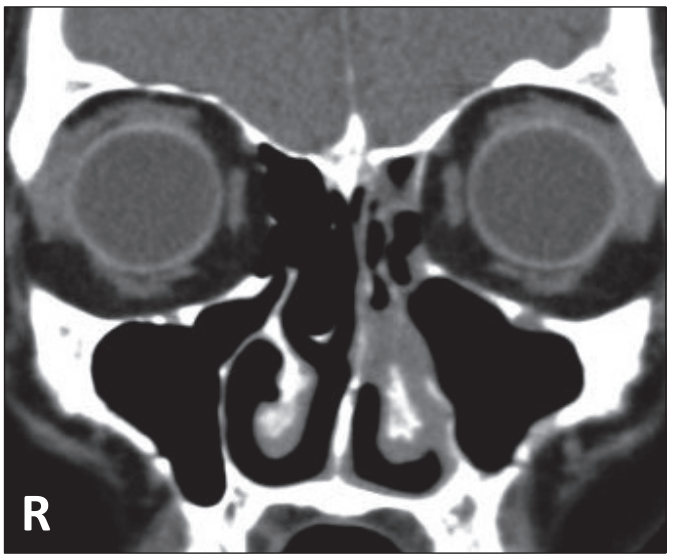

B

図 5 入院後 7 日目CT所見。A：左上顎洞陰影は改善するが一部貯留液が残存する。B：上顎洞，篩骨蜂巣ともに改善を認める。

を期待できたと考える。しかし外来受診時に心因反応に ともなう意識レベル低下があり内視鏡手術は難しいと判 断した。本症例は罹病期間が14日以上経過していたが, 全身状態や心身症状から上顎洞穿刺洗浄を選択した。上 顎洞洗浄は外来処置も可能であり本症例のような保存的 治療では改善が得られない例などでは選択肢の一つとし て考慮すべきである。

\section{2) サイノジェクトについて}

サイノジェクト ${ }^{\circledR}$ (ATOS Medical社製)（図 1) は上 顎洞穿刺・洗浄に使用する器具である ${ }^{3 \sim 6)}$ 。ボ夕ンをお すとスプリング式に作動し上顎洞側壁に押しあてること

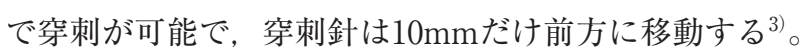
穿刺する際には上顎洞内に留置するためのステイチュー ブを針にセットし, 穿刺と同時にチューブが挿入される。 これまでの上顎洞探膿針のように膿汁の採取も可能であ る。ステイチューブの先端には小さい突起が付いている ため, 上顎内腔にひっかかることでチューブを留置し洗 浄処置を繰り返すことも可能である ${ }^{4)}$ 。サイノジェクト ${ }^{\circledR}$ はSchmidt針のように先端が彎曲していないため, 穿刺 の際には上顎洞側壁にできるだけ垂直になるように操作 することが必要である。サイノジェクト ${ }^{\circledR} の$ 利点は挿入 しすぎることがない, 少ない力で挿入が可能, チューブ の留置が可能なことである。一方で, 久点は垂直に押し つけるように操作しないと粘膜下に留置される, 上顎洞 内に留置される部分が短いため上顎洞内の粘膜腫脹が強 いと有効な上顎洞洗浄ができない, ことである。これま でのSchmidt針を用いた上顎洞洗浄と原理は同様で, 下 鼻道経由から内部の性状を確認することができ, 洗浄液 を注入することで上顎洞内の洗浄を行い上顎洞自然口よ り排泄される。従来の方法でも治療は可能であるが, 急
表 1 Schmidt針とサイノジェクトによる上䫟洞穿刺洗浄 の比較

\begin{tabular}{ccc}
\hline & Schmidt式 & サイノジェクト ${ }^{\circledR}$ \\
\hline 針または & $2 \mathrm{~mm}$ & $2 \mathrm{~mm}$ \\
チューブの径 & 可能 & 可能 \\
複数回の洗浄 & (その都度穿刺が必要) & (留置してもよい) \\
穿刺位置 & 下鼻道 & 下鼻道 \\
留置 & 不可能 & 可能 \\
禁忌 & なし & 歳以下の小児 \\
\hline
\end{tabular}

性副鼻腔炎に対する上顎洞洗浄は短期間に頻回の洗浄を 行うことが症状改善のために有用であり ${ }^{7)}$, 複数回洗浄 したい症例に対してサイノジェクトは短時間で穿刺で き, 留置が可能であることから侵襲が少なく有効に処置 ができる器具であると考える。それぞれの特徴を(表 1 ) に示す。当科では2006～2012年までの間に急性または慢 性副鼻腔炎に対し上顎洞穿刺・洗浄を行った症例は 7 例 あり, 従来のSchmidt針を用いたものは 2 例, サイノジェ クトを用いたものは 5 例であった。それぞれの使い分 けに明確な理由はないが，急性副鼻腔炎の症例で連日処 置ができる環境であればサイノジェクトを用いて チューブ留置していることが多い。疼痛改善の程度に明 らかな違いは認めなかった。Schmidt針を用いたもので は 1 回のみの穿刺・洗浄であったが, サイノジェクト ${ }^{\circledR}$ を用いた 5 例のうち 2 例では連日の洗浄を行い 1 例が改 善, 1 例が改善乏しく副鼻腔手術を行った。以上のよう に，当科では急性副鼻腔炎症例で短期間に集中的に洗浄 処置を行いたい場合にはサイノジェクトをを使うことで 患者の負担軽減や処置時間の短縮が図れると考えている。 
3）下鼻道に 2 本留置することの有用性

下鼻道経由の上顎洞洗浄では上顎洞内に留置した針ま たはチューブから洗浄液を注入し上顎洞自然口から膿汁 や粘液が排泄されることを期待している。急性上顎洞炎 の症例では中鼻道周囲の粘膜腫脹が強いことも多く, 洗 浄前にエピネフリンなどで中鼻道処置を行うことが重要 である6)。中鼻道が炎症により狭小化している場合やポ リープで充満している場合には排泄路が十分でなく眼窩 や㚘部の痛みを訴え処置を中止せざるを得ない場合もあ

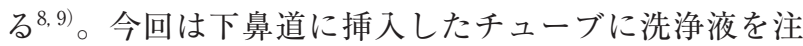
入することで疼痛の訴えがあり, 中鼻道の狭小, 粘膜腫 脹が原因と考えた。保存的治療で効果がそしいことや手 術治療が積極的に選択できない状況にあり，下鼻道後方 にさらに 2 本目のチューブ留置を行うこととした。2 本 目のチューブは洗浄液の排泄路として有効に働き, 疼痛 なく上顎洞洗浄が可能で所見の改善が得られた。過去に も上顎洞自然孔が閉塞する場合には穿刺針の近くにもう 1 本穿刺すると空気が入り, 吸引や洗浄がしやすくなる との報告がある9 ${ }^{9}$ 。Schmidt針を 2 本留置することは操 作空間の問題から困難であるが，ステイチューブは軟ら かく, 径も細いため 2 本の留置が可能であった。サイノ ジェクト ${ }^{\circledR}$ チューブを 2 本留置し洗浄の排泄路として 活用した報告は確認されず，今後中鼻道狭小のある症例 に上顎洞洗浄を行う場合，2本留置するということも選 択肢の一つとして考えたい。

\section{まとめ}

サイノジェクト®を用いて上顎洞洗浄を行った症例を 報告した。

中鼻道からの排泄が困難であったが，下鼻道に 2 本 チューブを留置することで上顎洞洗浄が有効に行うこと ができた。
本論文は第50回日本鼻科学会（岡山市）で要旨を発表 した。

\section{参考文献}

1) 高野信也, 川俣 光, 佐久間貴章, 他：急性副鼻腔 炎治療における耳鼻科的処置の有用性. 日鼻誌 $2001 ; 40: 96-98$.

2 ) 岡田修一：リスクマネージメント一外来処置・手術 とインフォームド・コンセント一上顎洞洗浄一。 日 耳鼻 $2005 ； 108 ： 182-185$.

3) Berg O, Lejdeborn L : Experience with a new puncture and irrigation system in the management of purulent maxillary sinusitis. Am J Rhinol $1992 ; 6: 13-16$.

4) Jurkiewicz D, Ligezinski A, Rapiejko P : Use of long-acting drainage (sino-ject) in treatment of chronic maxillary sinusitis. Pol Merkur Lekarski 1997 ; 3 : 274-278.

5 ) Wenig P, Heppt WJ, Maier H : Puncture of the maxillary sinus with the Sinoject. Laryngorhinootologie $1995 ; 74: 395-396$.

6 ）佐野真一：副鼻腔の穿刺・洗浄法. 浦野正美編.耳 鼻咽喉科の外来処置·外来小手術。中山書店，東京； 2012 : p114-119.

7 ）江崎史朗, 内田 豊：上顎洞穿刺・洗浄法. JOHNS $1991 ; 7: 1595-1603$.

8 ）平川勝洋：上顎洞穿刺検查. JOHNS $2010 ； 26$ : 1174-1178.

9）小川浩司：上顎洞穿刺 - 洗浄. JOHNS 1993；9： 1651-1653. 